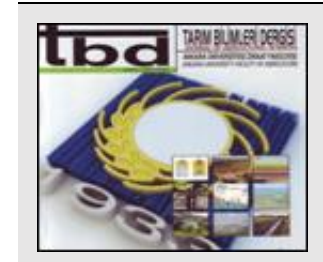

Tarım Bilimleri Dergisi

Journal of Agricultural Sciences

Tar. Bil. Der.

Dergi web sayfası:

www.agri.ankara.edu.tr/dergi

Journal homepage:

www.agri.ankara.edu.tr/journal

\title{
Use of Super Absorbent Polymers with Euonymus Plants (Euonymus japonicus 'Aureomarginatus') in Ornamental Plant Cultivation
}

\author{
İdris KARAGÖZZ ${ }^{a}$ Gül YÜCEL ${ }^{b}$

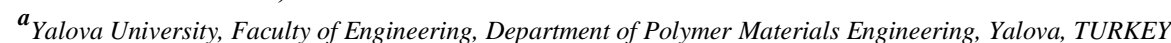

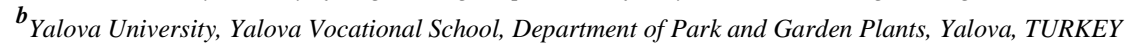

\section{ARTICLE INFO}

Research Article

Corresponding Author: İdris KARAGÖZ, E-mail: idris.karagoz@yalova.edu.tr, Tel: +90 (226) 8155553

Received: 17 October 2018, Received in Revised Form: 08 January 2019, Accepted: 26 March 2019

\author{
AUTHORS ORCID ID \\ (İdris KARAGÖZ:0000-0002-2644-8511), (Gül YÜCEL:0000-0003-1235-4482)
}

\begin{abstract}
In this study, the usability of super absorbent polymers (SAP) and its effects on water consumption, irrigation and labor costs and plant growth in ornamental plant cultivation were investigated by using Euonymus japonicus 'Aureomarginatus,' peat, river sand, and Wesoorb branded SAP. For a period of 152 days, the growth of the control groups without SAP and experimental groups with SAP was monitored, and the obtained results were compared. It
\end{abstract}

was determined that SAP balanced the moisture of the medium with a controlled release and decreased the water stress in the plant and differentiated the root structure. The use of SAP in Euonymus japonicus 'Aureomarginatus' cultivation reduced water use by $45 \%$ on average and labor costs by $48 \%$ on average. It was observed that SAP can be used in ornamental plant cultivation and will decrease production costs.

Keywords: Ornamental; Hydrogel; Sustainable; Water; Growth; Euonymus

(C) Ankara Üniversitesi Ziraat Fakültesi

\section{Introduction}

First synthesized in the United States towards the late 1950s, super absorbent polymers (SAPs) entered into industrial use in Europe and Japan in the 1970s (Trijasson et al 1990). Owing to their crosslinks, SAPs are insoluble in water, and can absorb 10 to 1.000 times their weight in water, saline water or physiological liquids (Pó 1994; Bhagat et al 2016). Their areas of use include diapers and disposable underpads (Trijasson et al 1990), wastewater treatment (Dhodapkar et al 2007; Bhagat et al 2016), hygienic products, sensors (Chen et al 2004), the pharmaceutical and drug sector (Mo et al 2006), the food sector (Casquilho et al 2013; Bhagat et al 2016), bioengineering (Bai et al 2013), biomedical technologies (del Valle et al 2017; Chatterjee et al 2018), and agricultural technologies (Mo et al 2006; Moslemi et al 2011; Bai et al 2013).

Potassium-containing polyacrylic- and polyacrylamide-based SAPs are widely used in agricultural applications (Ekebafe et al 2011; Moslemi et al 2011). Studies into SAP have investigated its ecotoxicological effects, revealing no toxic effect on water and soil (Madakbaş et al 2014; Bhagat et al 2016). In contrast, it has been reported that a controlled application could improve or control microbial activity (Li et al 2014). Previous studies have suggested that SAP can accelerate plant growth by promoting fertilizer retention (İsmail \& Kuyulu 2003), and that a plant's level of interaction with its environment varies according to the quantity of administered SAP, which in turn increases product yield by reducing water-based stress (Sayyari \& Ghanbari 2012). It has been also reported that 
SAP increases plant diameter, size, leaf number and leaf width; boosts shoot formation and root growth; and extends plant lifespan (Ruqin et al 2015; Souza et al 2016). Its use on seeds normally involves covering seeds with SAP or germinating them within SAP, while use on plant roots involves application of SAP in gel form (Madakbaş et al 2014). In the literature reviews, it was determined that the studies were generally carried out on fruit and vegetable cultivation (Madakbaş et al 2014) and increase of product yield (Sayyari \& Ghanbari 2012), similar studies have been conducted on ornamental plants such as tropical ornamental plants (Wang 1989), coarsestructured garden plants (Fonteno \& Bilderback 1993), Cupressus arizonica (Koupai \& Asadkazemi 2006), tree seedlings (Orikiriza et al 2013), ornamental Salvia species (Ljubojević et al 2017), but there is no study conducted on Euonymus japonicus which is frequently used in plant design applications (Gül et al 2006; Eren \& Var 2016) and has high water needs (Gül et al 2006).

In this study, it was aimed to investigate the effects of SAP usage on water consumption, irrigation and labor costs, plant shoot and root growth in Euonymus japonicus 'Aureomarginatus' cultivation environment. For a period of 152 days, the growth of the control groups without SAP and experimental groups with SAP was monitored, and the results were compared to determine the effects of SAP on water usage, costs, and plant growth.

\section{Material and Methods}

\subsection{Preparation of materials and samples}

The peat and Euonymus japonicus 'Aureomarginatus' used in the study trials were commercially supplied by Göker Agriculture (Yalova, Turkey), while the Wesoorb-branded SAP was supplied by Ecotech Co. Ltd. (Izmir, Turkey). For each pot, Wesoorb-branded SAP in powder form was manually added to peat or river sand in the quantities indicated in Table 1 and mixed thoroughly to ensure equal distribution. Euonymus japonicus 'Aureomarginatus' seedlings were planted in $1.5 \mathrm{~L}$ flowerpots taking into account the maximum water holding capacity of SAP and leaving a 20\% irrigation gap from the top surface, and they were labeled and taken into the greenhouse environment. HUBO-branded UX100-003 temperature and humidity dataloggers (temp/RH loggers) placed at different points provided continuous monitoring of the temperature and humidity in the greenhouse.

Table 1- Parameters used in the study

\begin{tabular}{lcccc}
\hline Code & $\begin{array}{c}\text { Peat } \\
(g)\end{array}$ & $\begin{array}{c}\text { River sand } \\
(g)\end{array}$ & $\begin{array}{c}\text { SAP } \\
(g)\end{array}$ & $\begin{array}{c}\text { Number of } \\
\text { plants }\end{array}$ \\
\hline R-1 & 1.200 & - & - & 45 \\
R-2 & - & 1.200 & - & 45 \\
TS-1 & 1.200 & - & 0.8 & 45 \\
TS-2 & 1.200 & - & 1.0 & 45 \\
TS-3 & 1.200 & - & 1.2 & 45 \\
KS-1 & - & 1.200 & 0.8 & 45 \\
KS-2 & - & 1.200 & 1.0 & 45 \\
KS-3 & - & 1.200 & 1.2 & 45 \\
\hline
\end{tabular}

\subsection{Characterization}

The IR spectrum of the SAP additive in pellet form was taken at room temperature using a Perkin Elmer Spectrum 100 FT-IR device, with the aim of determining the groups attached to the monomer units. An Olympus BX51M optical microscope was used to measure the particle size of the SAP additive so as to determine average particle size and surface morphology. The determination of the water retention capacity $(\mathrm{Q})$ of SAP, as well as the 
absorption test (Bakass et al 2002; İsmail \& Kuyulu 2003; Bai et al 2013) and the desorption tests (İsmail \& Kuyulu 2003; Mo et al 2006; Bai et al 2013) of peat and sand were all carried out as described in literature.

The level of moisture of the cultivation medium was measured daily with a Tartes Decagon-01-branded digital soil moisture meter. After planting, the pots were weighed, and their initial conditions were recorded. At first, irrigation was performed from the top in a way to wet the entire surface of the soil in order to determine the water holding capacity of the medium. At the point when the water started to flow through the drainage holes, irrigation was stopped, and the pots were weighed again. By using similar studies in the literature (İsmail \& Kuyulu 2003), the maximum water capacity that the soil can hold without drainage was determined by comparing the measured weight with the initial weight. Similarly, to the study carried out by Gao et al (2013), different ratios of water between $20 \%$ and $25 \%$ of the volume of the root medium, $500 \mathrm{~mL}$ for each pot, was given for the formation of adequate drainage and for determining the amount of irrigation (Connellan 2002; Gao et al 2013; Varıș 2017). An attempt to determine the optimum amount of irrigation was made by performing drainage measurements and weighing the pots.

The seedling size and dry root weight measurements performed before planting were repeated at one-month intervals, to monitor plant growth on a monthly basis. The plants were pruned at the end of the second and fourth months, and the pruned plant parts were weighed on a precision scale to determine the effect of SAP on shoot formation.

\subsection{Calculation of costs}

Formula number 1 was used in the calculation of the total amount of water used (TW) depending on the amount of water used in irrigation $(W)$ and the number of irrigation repetitions $(Q)$ by determining from drainage measurements. While the cost of water used (WP) was calculated from formula number two, irrigation labor costs $(L C)$ and total cost $(T C)$ were calculated from formulae number three and four, respectively. The unit water prices for public institutions of Yalova Municipality $(U P)$ were used as a basis in the calculation of WP. The seasonal worker wage $(d L C)$ depending on the number of days worked was used in the calculation of $L C$. The studies of Ahmed et al (2013), Kim et al (2015), Kumar (2015) and Landscheidt \& Kans (2016) were used for the formulae used in cost calculations.

$$
\begin{aligned}
& T W(L)=W(L) \times Q \\
& W P(\notin)=T W(L) \times U P(\notin / L) \\
& L C(\leftleftarrows)=Q \times d L C(\hbar) \\
& T C(£)=W P(£)+L C(£)
\end{aligned}
$$

The amounts of savings in labor costs and water usage were determined by proportioning the data obtained from the control group to the data obtained from the experimental group. The results obtained from cost calculations were compared with the results of similar studies in the literature (Nnadi 2012; Madakbaş et al 2014; Bhagat et al 2016).

\section{Results and Discussion}

\subsection{FT-IR spectrum}

Figure 1 shows the IR spectra of the acrylamide and potassium acrylate copolymers. The peak observed at the $1691 \mathrm{~cm}^{-1}$ wavelength corresponds to the hydrogen bond made by an $\mathrm{NH}_{2}$ group in the acrylamide structure (Chen et al 2004). The peaks between $1400 \mathrm{~cm}^{-1}$ and $1600 \mathrm{~cm}^{-1}$ are possibly stretching vibrations associated with $\mathrm{CH}_{2}$. The peaks near the $1100 \mathrm{~cm}^{-1}$ wavelength correspond to $\mathrm{C}=\mathrm{O}$ bond stretching in the carboxyl acid structure. The aliphatic C-H stretching vibrations within the structure are observed between the $2700-2929 \mathrm{~cm}^{-1}$ wavelengths (Durukan 2007). The IR data suggests that the monomeric units are bonded in a graft copolymer arrangement (Chen et al 2004).

Tarım Bilimleri Dergisi - Journal of Agricultural Sciences 26 (2020) 201-211 


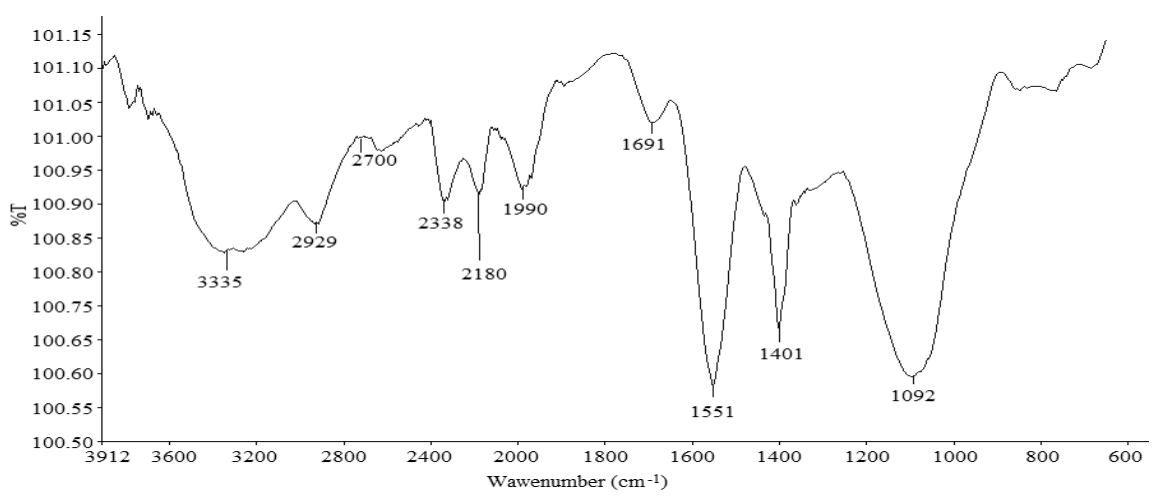

Figure 1- IR spectra of acrylamide and potassium acrylate copolymer

\subsection{Optical microscope examination}

The average particle size of SAP, whose optical microscope image is shown in Figure 2, was calculated as $150 \mu$. The particle sizes varied between 80 and $250 \mu$, and this variation is assumed to have an effect on water retention capacity. Trijasson et al (1990) described similar results in their study.

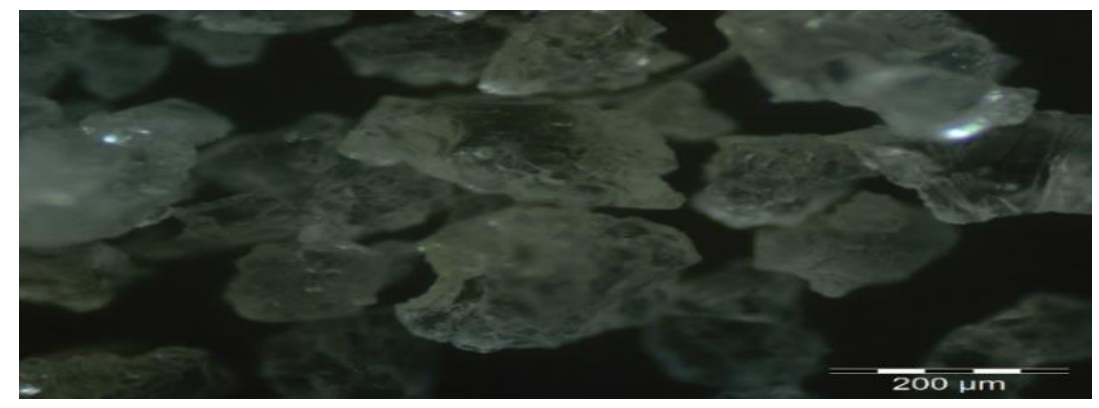

Figure 2- Stereomicroscopy image of particles

\subsection{Characterization of the SAP additive}

The water retention capacity of SAP when dry was found to be 250 times its weight, while its water absorption speed was 8-15 minutes. Absorption occurred rapidly during the first eight minutes, reaching a steady pace in approximately 40 minutes. The SAP absorption graph and desorption graph are presented in Figures 3.a and 3.b, respectively. The soil contraction that formed depending on the SAP ratio and water loss resulted in a pressure on SAP that accelerated the rate of desorption. İsmail \& Kuyulu (2003), Mo et al (2006) and Bai et al (2013) described similar results in their study.
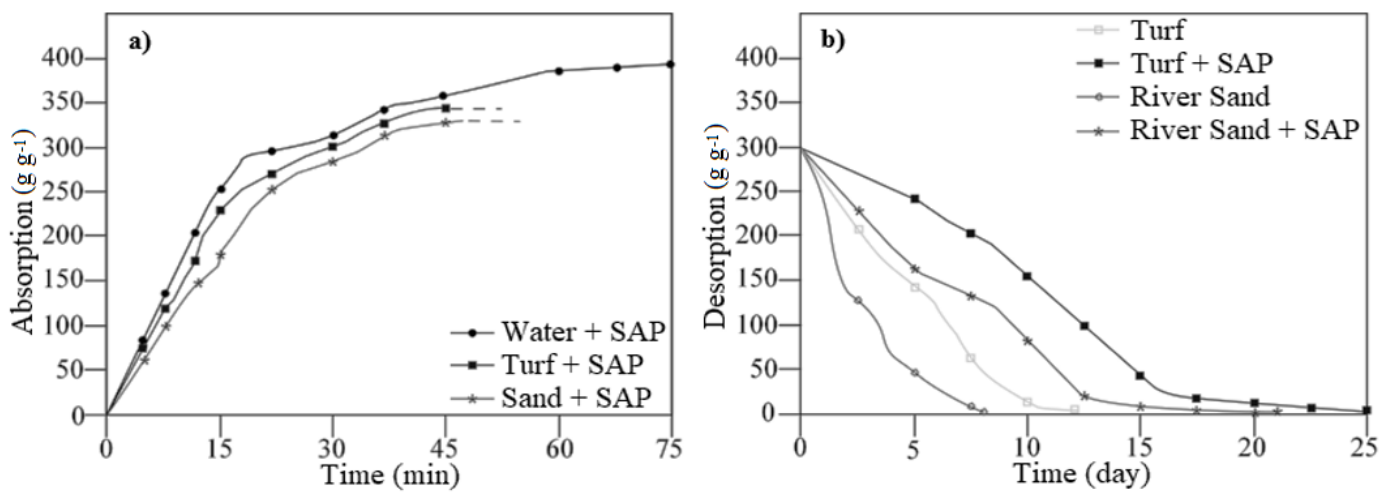

Figure 3- a) SAPs Absorption and b) SAPs Desorption graph 
The medium designated as TS-3 had the longest intervals between watering, with 22 days between each watering, while the medium designated as R-2 had the shortest interval, with six days between each watering. The SAP ratios, the watering intervals according to the cultivation medium, and the amounts of water used over the 152 days are shown in Table 2.

Table 2- The amount of water used in the study

\begin{tabular}{lccc} 
Code & $\begin{array}{c}\text { Interval between } \\
\text { each watering } \\
(d)\end{array}$ & $\begin{array}{c}\text { Number of } \\
\text { watering }\end{array}$ & $\begin{array}{c}\text { Amount of water } \\
\text { used } \\
(\mathrm{mL})\end{array}$ \\
\hline R-1 & 10 & 15 & 5.000 \\
TS-1 & 17 & 9 & 3.200 \\
TS-2 & 20 & 7 & 2.600 \\
TS-3 & 22 & 6 & 2.300 \\
R-2 & 6 & 25 & 8.000 \\
KS-1 & 9 & 16 & 5.300 \\
KS-2 & 11 & 13 & 4.400 \\
KS-3 & 14 & 11 & 3.800 \\
\hline
\end{tabular}

\subsection{Determination of water holding capacity and the amount of irrigation water}

Water holding capacity without drainage was calculated to be $240 \mathrm{~mL}$ for turf and $108 \mathrm{~mL}$ for sand. It was observed that similar results were obtained with the calculations made by Connellan (2002). It was determined that the amount of $300 \mathrm{~mL}$ irrigation water, which is $25 \%$ of the total root media, provided adequate drainage in the pot and was the ideal amount of water to be used in irrigation periods. The results obtained from drainage measurements were observed to be consistent with the studies aimed at determining the adequate amount of drainage in pot plants (Varış 2017).

\subsection{Humidity measurement results}

Relative humidity inside the greenhouse was 55-60 percent in the morning and 90-95 percent at night, while the average temperature values were $25^{\circ} \mathrm{C}$ in the morning and $17^{\circ} \mathrm{C}$ at night.

The daily soil moisture measurements showed that the water absorbed by SAP - depending on the time, ambient temperature, evaporation and soil moisture loss - is later released, ensuring that the soil remains moist (İsmail \& Kuyulu 2003; Casquilho et al 2013). In a peat-based medium, SAP formed tiny islets that provided humidity by releasing previously absorbed water at a balanced rate. The structure of peat ensured that the medium stayed humid for longer periods. In the sandy media, the sand particles carried the water absorbed by SAP into the medium. It is thought that the speed at which water is carried in a sandy medium affects its ambient humidity, and that this leads to greater humidity loss when compared to the fully peat medium (Chen et al 2004). The soil humidity measurement results, which were taken daily and determined using weighted averages, are given in Table 3 . The results indicate that humidity, which has an important effect on the environment/medium, can be controlled by using SAP; that SAP will prevent the unnecessary use of water to ensure the effective use of irrigation systems; and that the environment/medium has a significant effect on humidity. Chen et al (2004) and Souza et al (2016) reported similar results in their study.

The increased addition of SAP to a peat-based medium decreased the level of humidity within the medium, while adding more SAP to a sand river-based medium increased the level of humidity within the medium. The decrease in humidity in the peat medium was related to the water retention capacity of peat, with the water held inside the peat being absorbed by the SAP. On the other hand, adding SAP to a sandy medium resulted in the medium remaining more humid, depending on the amount of SAP used (Chen et al 2004). Measurements performed after irrigation indicated that the SAP allowed both types of medium to remain humid for longer. The peat medium remained humid for longer, despite watering at greater time intervals. 
Table 3- Moisture content of soil

\begin{tabular}{|c|c|c|c|c|c|c|c|c|}
\hline \multicolumn{9}{|c|}{ Moisture content of soil (\%) } \\
\hline $\operatorname{Day}(d)$ & $R-1^{*}$ & $T S-1^{*}$ & $T S-2^{*}$ & $T S-3^{*}$ & $R-2^{*}$ & $K S-1^{*}$ & $K S-2^{*}$ & $K S-3^{*}$ \\
\hline 1 & $37.4^{\mathrm{a}}$ & $38.1^{\mathrm{b}}$ & $37.8^{\mathrm{a}}$ & $37.5^{\mathrm{a}}$ & $22.0^{\mathrm{a}}$ & $22.5^{\mathrm{b}}$ & $23.0^{\mathrm{c}}$ & $24.4^{\mathrm{a}}$ \\
\hline 2 & $34.8^{\mathrm{a}}$ & $36.8^{\mathrm{a}}$ & $36.7^{\mathrm{c}}$ & $36.6^{\mathrm{c}}$ & $18.4^{\mathrm{e}}$ & $20.5^{\mathrm{b}}$ & $21.2^{\mathrm{a}}$ & $23.1^{b}$ \\
\hline 3 & $32.6^{\mathrm{c}}$ & $35.4^{\mathrm{b}}$ & $35.6^{\mathrm{a}}$ & $35.7^{\mathrm{c}}$ & $14.7^{\mathrm{f}}$ & $17.4^{\mathrm{a}}$ & $19.5^{\mathrm{b}}$ & $21.7^{\mathrm{a}}$ \\
\hline 4 & $29.8^{\mathrm{d}}$ & $33.9^{b}$ & $34.6^{\mathrm{b}}$ & $34.7^{\mathrm{a}}$ & $11.1^{\mathrm{a}}$ & $16.6^{\mathrm{c}}$ & $17.6^{\mathrm{c}}$ & $20.1^{b}$ \\
\hline 5 & $27.4^{\mathrm{b}}$ & $32.5^{\mathrm{b}}$ & $33.5^{\mathrm{a}}$ & $33.8^{\mathrm{d}}$ & $7.1^{\mathrm{b}}$ & $14.7^{\mathrm{d}}$ & $15.8^{\mathrm{a}}$ & $18.9^{\mathrm{c}}$ \\
\hline 6 & $24.7^{\mathrm{b}}$ & $31.1^{\mathrm{c}}$ & $32.5^{\mathrm{b}}$ & $32.9^{f}$ & $3.8^{\mathrm{a}}$ & $12.6^{\mathrm{d}}$ & $13.9^{\mathrm{a}}$ & $17.5^{\mathrm{d}}$ \\
\hline 7 & $21.9^{c}$ & $29.8^{\mathrm{e}}$ & $31.4^{\mathrm{d}}$ & $31.9^{b}$ & - & $10.7^{\mathrm{b}}$ & $12.1^{\mathrm{d}}$ & $16.0^{\mathrm{a}}$ \\
\hline 8 & $19.6^{\mathrm{e}}$ & $28.4^{\mathrm{d}}$ & $30.3^{c}$ & $31.1^{\mathrm{d}}$ & - & $8.8^{\mathrm{e}}$ & $10.4^{\mathrm{a}}$ & $14.7^{c}$ \\
\hline 9 & $16.7^{f}$ & $26.9^{c}$ & $29.4^{\mathrm{b}}$ & $30.2^{\mathrm{a}}$ & - & $4.7^{\mathrm{c}}$ & $8.6^{\mathrm{e}}$ & $13.3^{c}$ \\
\hline 10 & $14.4^{\mathrm{a}}$ & $25.5^{\mathrm{c}}$ & $28.3^{\mathrm{a}}$ & $29.2^{\mathrm{a}}$ & - & - & $6.8^{\mathrm{a}}$ & $11.9^{b}$ \\
\hline 11 & - & $24.1^{\mathrm{c}}$ & $27.1^{\mathrm{d}}$ & $28.3^{c}$ & - & - & $5.2^{\mathrm{d}}$ & $10.5^{\mathrm{e}}$ \\
\hline 12 & - & $22.7^{b}$ & $26.2^{\mathrm{b}}$ & $27.4^{\mathrm{c}}$ & - & - & - & $9.1^{\mathrm{a}}$ \\
\hline 13 & - & $21.3^{c}$ & $25.0^{\mathrm{b}}$ & $26.5^{\mathrm{e}}$ & - & - & - & $7.7^{\mathrm{e}}$ \\
\hline 14 & - & $19.9^{\mathrm{e}}$ & $23.9^{c}$ & $25.5^{\mathrm{b}}$ & - & - & - & $6.3^{\mathrm{d}}$ \\
\hline 15 & - & $18.5^{\mathrm{f}}$ & $22.9^{\mathrm{d}}$ & $24.6^{\mathrm{b}}$ & - & - & - & - \\
\hline 16 & - & $17.0^{\mathrm{b}}$ & $21.7^{\mathrm{a}}$ & $26.7^{\mathrm{a}}$ & - & - & - & - \\
\hline 17 & - & $15.5^{\mathrm{a}}$ & $20.5^{b}$ & $22.7^{\mathrm{d}}$ & - & - & - & - \\
\hline 18 & - & - & $19.6^{\mathrm{b}}$ & $21.8^{\mathrm{b}}$ & - & - & - & - \\
\hline 19 & - & - & $18.4^{\mathrm{c}}$ & $20.9^{c}$ & - & - & - & - \\
\hline 20 & - & - & $17.6^{\mathrm{b}}$ & $19.9^{\mathrm{d}}$ & - & - & - & - \\
\hline 21 & - & - & - & $19.0^{c}$ & - & - & - & - \\
\hline 22 & - & - & - & $18.2^{\mathrm{e}}$ & - & - & - & - \\
\hline
\end{tabular}

*, $\mathrm{P}<0.05$; numbers in the same column with the same letter are not significantly different

\subsection{Effects on plant shoot development}

During planting, the average plant size was measured as $11 \mathrm{~cm}$. A graph indicating plant size growth, based on measurements performed in succeeding months, is shown in Figure 4. The shoot size measurements made in the first month in both the control and trial groups gave higher values when compared to the following months. This is believed to have stemmed from the plant's transition from the seedling medium to the richer and larger cultivation medium, and also from the fact that this period coincided with the start of the vegetation period. A comparison of the control and trial groups revealed that plants in the SAP-added media exhibited greater total size growth than those in the control groups. This observation can be explained by the balanced humidity that SAP ensured in the medium until the next irrigation time, which reduced plant water stress and promoted plant growth (Chen et al 2004; Casquilho et al 2013).

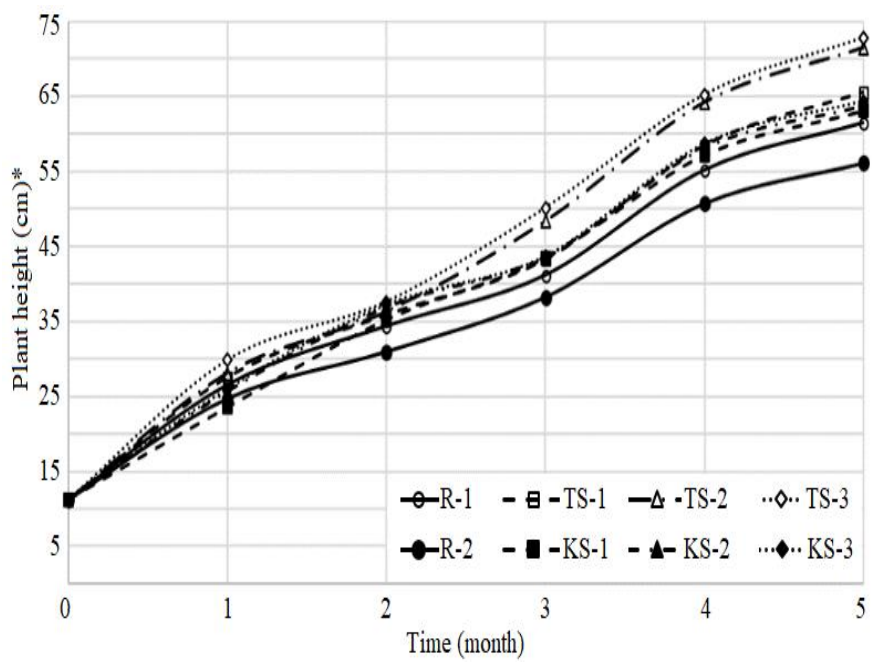

Figure 4- Plant height development chart $\left({ }^{*} \mathrm{P} \leq 0.05\right)$ 
In both growth media, an increasing quantity of SAP resulted in increased plant size. The best size growth was obtained in the peat media with SAP added. On the other hand, the level of plant growth in river sand media with SAP was similar to the one observed in the peat media without SAP. SAP added to river sand promoted plant growth by maintaining the absorbed water within the medium and preventing rapid evaporation (Moslemi et al 2011).

An effect similar to the one on shoot size was also observed on shoot growth density, which is measured based on shoot size, number of shoots and stem thickness. The size, biomass weight and growth density of the pruned plant parts are presented as a graph in Figure 5. The best growth density was seen in the trial group designated TS3 , and plant growth in the peat+SAP cultivation medium was generally measured as being better when compared to the river sand+SAP medium. Growth density in the trial groups was higher than in the control groups. In both types of cultivation media, the higher the addition of SAP, the higher the plant growth density was (Li et al 2014). Compared to the control samples, SAP addition accelerated plant growth without altering the plant growth balance. The fact that the plant growth density remained the same despite the increase in plant size, leaf and shoot number, and in the biomass of pruned plant parts suggested that the plants' growth remained controlled and balanced. This is further confirmed by the fact that in both the control and trial groups, the growth density at the end of the second and fourth months were at the same levels as in the preceding months. The humidity balance also affected plant growth, with higher levels of humidity that lasted longer resulting in higher plant growth density (Casquilho et al 2013).

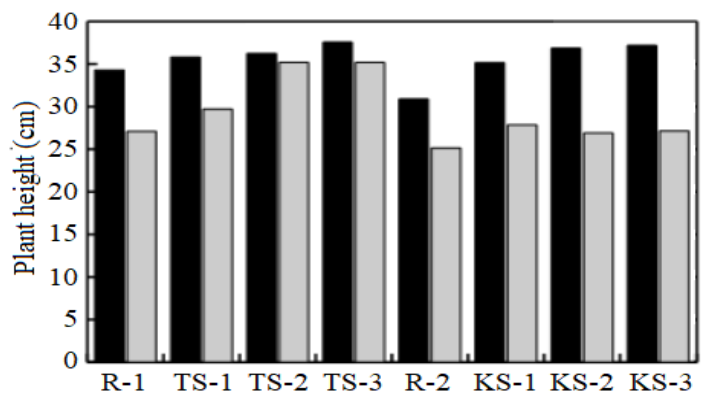

a) Plant height

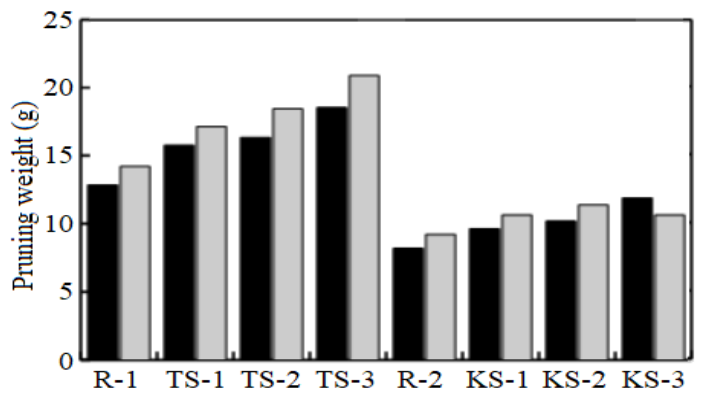

b) Pruning weight

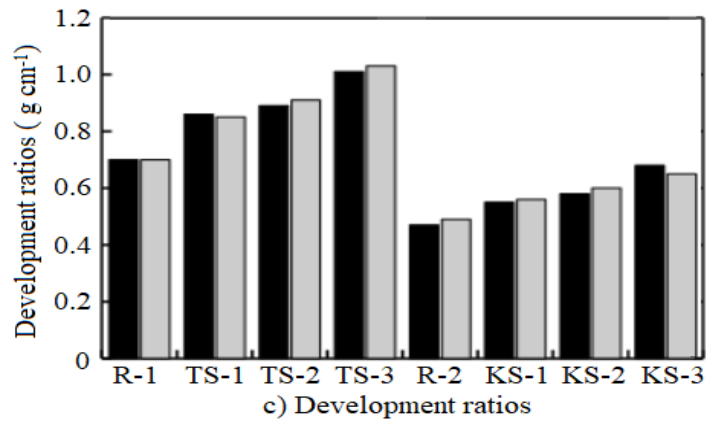

1 st pruning 2nd pruning

Figure 5- Height, weight and development ratios after pruning

\subsection{Effects on plant root development}

The average pre-planting root weights of the seedlings was $8.5 \mathrm{~g}$. Figure 6 shows the five-month development of root weight. The monthly measurements revealed that the intervention group had a higher dry root weight than the control group. Euonymus japonicus plant roots in a peat medium were less numerous yet thicker when compared to the sand medium, while roots in the sand medium were more numerous yet thinner compared to the peat medium. This suggested that the sandy medium caused the plant to form more roots in different directions in order to reach water (Figure 7). The data presented in Figure 6 and Figure 7 show that while SAP had an effect on rooting, actual root formation varied according to the type of medium and the amount of SAP (Sayyari \& Ghanbari 2012). 


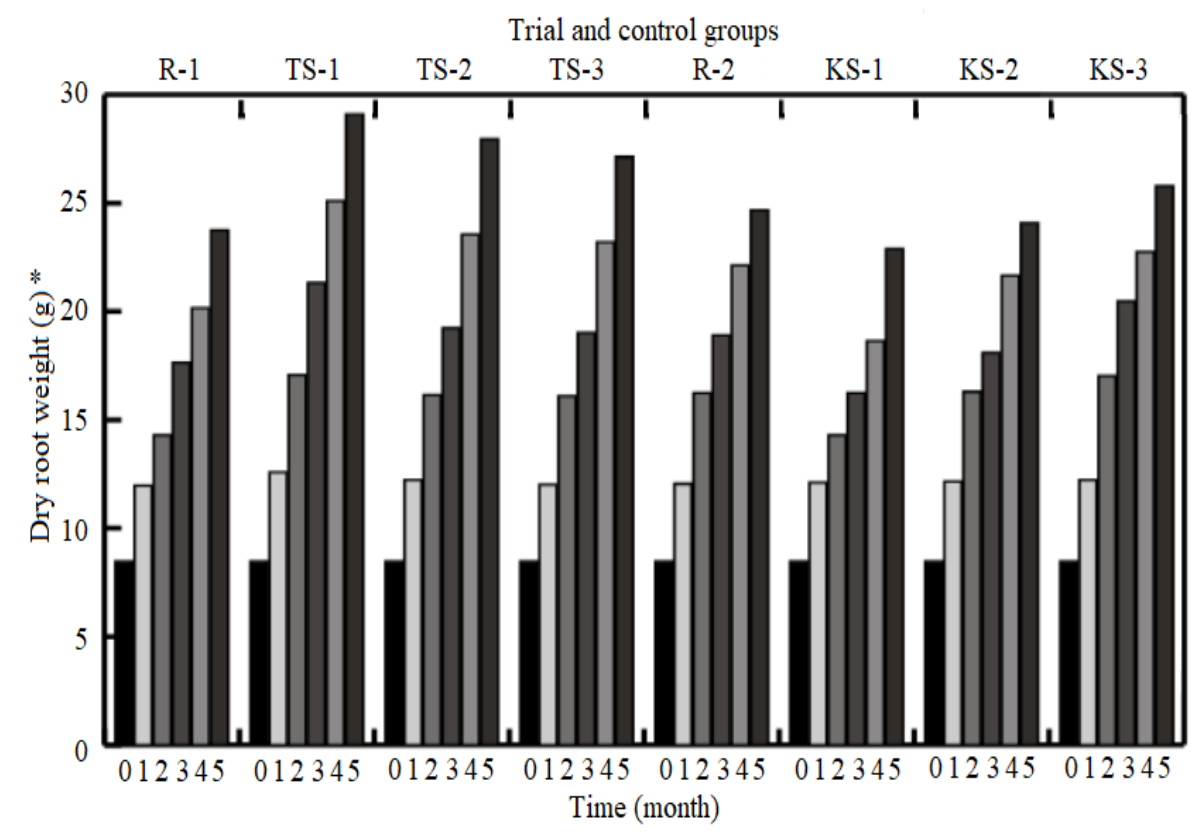

Figure 6- Monthly dry root weight chart of the trial and control groups $(*, P \leq 0.05)$

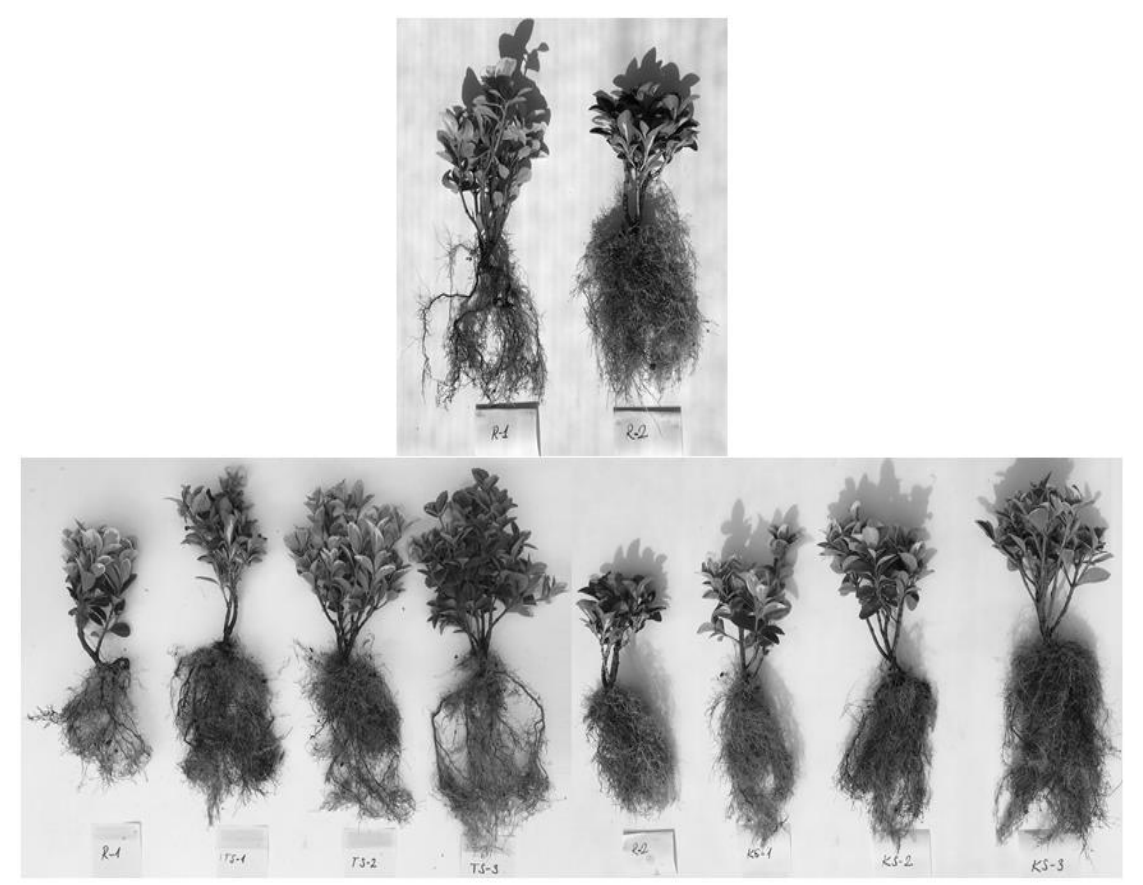

Figure 7- Root formation according to the type of medium and the amount of SAP

\subsection{Calculation of labor costs}

Irrigation and labor costs are presented in Table 4. When turf and SAP were used together, the average savings of $46 \%$ and the average savings of $51 \%$ were achieved in water usage and labor costs, respectively. When river sand and SAP were used together, there was an average reduction of $44 \%$ in water usage and an average reduction of $47 \%$ in labor costs. It was also stated by Nnadi (2012), Madakbaş et al (2014) and Bhagat et al (2016), that the irrigation of plants based on certain periods reduced labor costs and water usage by $30 \%-50 \%$ when SAP was used. 
Table 4- Comparison of irrigation and labor costs

\begin{tabular}{lcccrr}
\hline Code & $\begin{array}{c}\text { Labor Cost } \\
(T L)\end{array}$ & $\begin{array}{c}\text { Labor Cost-saving } \\
(\%)\end{array}$ & $\begin{array}{c}\text { Water cost } \\
(\text { TL) }\end{array}$ & $\begin{array}{r}\text { Water-saving } \\
(\%)\end{array}$ & $\begin{array}{r}\text { Total cost } \\
(\text { TL) }\end{array}$ \\
\hline R-1 & 1.500 & - & 40.40 & - & 1.540 .40 \\
TS-1 & 900 & $40^{*}$ & 25.85 & $36^{*}$ & 964.65 \\
TS-2 & 700 & $53^{*}$ & 21.00 & $48^{*}$ & 725.85 \\
TS-3 & 600 & $60^{*}$ & 18.60 & $54^{*}$ & 621,00 \\
R-2 & 2.500 & - & 64.65 & - & 2.518 .60 \\
KS-1 & 1.600 & $36^{*}$ & 42.85 & $34^{*}$ & 1.642 .85 \\
KS-2 & 1.300 & $48^{*}$ & 35.55 & $45^{*}$ & 1.335 .55 \\
KS-3 & 1.100 & $56^{*}$ & 30.70 & $52^{*}$ & 1.130 .70 \\
\hline
\end{tabular}

*, calculated by proportioning the data from the control group with the data from the trial group

\section{Conclusions}

This study based on the Euonymus japonicus 'Aureomarginatus' demonstrated the significance of the use of SAP within the cultivation medium in ensuring and maintaining balanced humidity. Depending on the amount of SAP used, the amount of water retained in the medium increased, along with the shoot formation ratio and root development. SAP was thus found to be usable in the cultivation of ornamental plants. Depending on the cultivation medium and the amount of SAP, SAP use resulted in an average decrease in water use of $45 \%$, and an average decrease in labor costs of $49 \%$.

\section{Acknowledgements}

The authors would like to thank the Scientific Research Projects Commission of Yalova University for their support of project number 2016/AP/138.

\section{References}

Ahmed E M, Aggor F S \& Hawash S I (2013). Feasibility and relevant cost indicators of superabsorbent hydrogel produced in Egypt. Journal of Applied Sciences Research 9(4): 3045-3049

Bai W, Song J \& Zhang H (2013). Repeated water absorbency of super-absorbent polymers in agricultural field applications: a simulation study. Acta Agriculturae. Scandinavica. Section B 63(5): 433-441

Bakass M, Mokhlisse A \& Lallemant M (2002). Absorption and desorption of liquid water by a superabsorbent polymer: Effect of polymer in the drying of the soil and the quality of certain plants. Journal of Applied Polymer Science 83: 234-243

Bhagat M S, Ghare A D \& Ralegaonkar R V (2016). Application of super absorbent polymer in flood management and agricultural water management. Journal of Resarch in Engineering and Applied Sciences 1(1): 30-36

Casquilho M, Rodrigues A \& Rosa F (2013). Superabsorbent polymer for water management in forestry. Agricultural Sciences 4(5B): 57-60

Chatterjee S, Hui P C \& Kan C (2018). Thermoresponsive hydrogels and their biomedical applications: Special insight into their applications in textile based transdermal therapy. Polymers 10(5): 480

Chen P, Zhang W, Luo W \& Fang Y (2004). Synthesis of superabsorbent polymers by irradiation and their applications in agriculture. Journal Applied Polymer Sciences 93: 1748-1755

Connellan G (2002). Efficient Irrigation: A reference manual for turf and landscape. Irrigation best management training program report, School of resource management and geography, University of Melbourne (Unpublished), AU

del Valle L J, Diaz A \& Puiggali J (2017). Hydrogels for biomedical applications: Cellulose, chitosan, and protein/peptide derivates. Gels 3(3): 27

Dhodapkar R, Rao N N, Pande S P, Nandy T \& Devotta S (2007). Adsorption of cationic dyes on Jalshakti ${ }^{\circledR}$, super absorbent polymer and photocatalytic regeneration of the adsorbent. Reactive \& Functional Polymers 67: 540-548

Tarım Bilimleri Dergisi - Journal of Agricultural Sciences 26 (2020) 201-211 
Durukan H B (2007). Preparation, characterization and investigation of adsorption properties of chemically crosslinked acrylamide/citraconic acid/sodium acrylate terpolymers. M.Sc. Thesis, Adnan Menderes University (Unpublished), Turkey

Ekebafe L O, Ogbeifun D E \& Okieimen F E (2011). Polymer applications in agriculture. Biokemistri 23(2): 81-89

Eren E T \& Var M (2016). Taxa used in planting design in parks: The case of Trabzon city centre. Artvin Çoruh University Journal of Forestry Faculty 17(2): 200-213

Fonteno W C \& Bilderback T E (1993). Impact of hydrogel on physical properties of coarse-structured horticultural substrates. Journal of the American Society for Horticultural Science 118(2): 217-222

Gao L, Wang S \& Zhao X (2013). Synthesis and characterization of agricultural controllable humic acid superabsorbent. Journal of Environmental Sciences 25: 69-76

Gül E, Abay G \& Kuter N (2006). Trees and shrubs in the parks and gardens of Çankırı. Artvin Çoruh University Journal of Forestry Faculty 7(1): 60-65

İsmail O \& Kuyulu A (2003). Synthesis of superabsorbent copolymers based on acrylic acid and their horticultural applications. Journal of Ylldiz Technical University 3: 33-40

Kim S, Ko W \& Bang S (2015). Analysis of unit process cost for an engineering-scale pyroprocess facility using a process costing methon in Korea. Energies 8: 8775-8797

Koupai J A \& Asadkazemi J (2006). Effects of a hydrophilic polymer on the field performance of an ornamental plant (Cupressus arizonica) under reduced irrigation regimes. Iranian Polymer Journal 15(9): 715-725

Kumar R (2015). Evaluation of hydrogel on the performance of rabi maize (Zea mays L.). MSc Thesis, Bihar Agricultural University (Unpublished), India

Landscheidt S \& Kans M (2016). Method for assessing the total cost of ownership of industrial robots. $49^{\text {th }}$ CIRP Conference on Manufacturing Systems 25-27 May 57: 746-751

Li X, He J Z, Hughes J M, Liu Y R \& Zheng Y M (2014). Effects of super-absorbent polymers on a soil-wheat (Triticum aestivum L.) system in the field. Applied Soil Ecology 73: 58-63

Ljubojević M, Ognjanov V, Maksimovic I, Čukanović J, Dulić J, Szabò Z \& Szabò E (2017). Effects of hydrogel on growth and visual damage of ornamental Salvia species exposed to salinity. Clean-Soil, Air, Water 45: 1-8

Madakbaş S Y, Önal M S, Dündar B \& Başak H (2014). Soil and plant functions of water holding polymers, environmental impact and possibilities of their use in vegetable. Turkish Journal of Agricultural and Natural Sciences 1(2): 173-179

Mo C, Shu-quan Z, Hua-Min L, Zhan-bin H \& Shu-qin L (2006). Synthesis of poly(acrylic acid)/sodium humate superabsorbent composite for agricultural use. Journal Applied Polymer Sciences 102: 5137-5143

Moslemi Z, Habibi D, Asgharzadeh A, Ardakani M R, Mohammadi A \& Sakari A (2011). Effects of super absorbent polymer and plant growth promoting rhizobacteria on yield and yield components of maize under drought stress and normal conditions. African Journal of Agricultural Research 6(19): 4471-4476

Nnadi (2012). Super Absorbent Polymer (SAP) and irrigation water sonservation. Irrigation \& Drainage Systems Engineering 1: $1-2$

Orikiriza L J B, Agaba H, Eilu G, Kabasa J D, Worbes M \& Hütterman A (2013). Effects of hydrogels on tree seedling performance in temperate soils before and after water stress. Journal of Environmental Protection 4: 713-721

Pó R (1994). Water-absorbent polymers: A patent survey. Journal of Macromolecular. Science Part C 34(4): 607-662

Ruqin F, Jia L, Shaohua Y, Yunlai Z \& Zhenhua Z (2015). Effects of biochar and super absorbent polymer on substrate properties and water spinach growth. Pedosphere 25(5): 737-748

Sayyari M \& Ghanbari F (2012). Effects of super absorbent polymer A200 on the growth, yield ans some physiological responses in sweet pepper (Capsicum Annuит L.) under various irrigation regimes. International Journal of Agriccultural and Food Research 1(1): 1-11 
Souza A J J, Guimarães R J, Colombo A, Sant'Ana J A V \& Castanheira D T (2016). Quantitative analysis of growth in coffee plants cultivated with a water-retaining polymer in an irrigated system. The Revista Ciência Agronômica 47(1): 162-171

Trijasson P, Pith T \& Lambla M (1990). Hydrophilic polyelectrolyte gels by inverse suspansion. Macromolecular Symposia 35/36: $141-169$

Varış S (2017). Saksılı bitkilerde sulama bilimi ve sanatı. Plant 7: 204-211

Wang Y T (1989). Medium and hydrogel affect production and wilting of tropical ornamental plants. HortScience 24(6): 941-945 